\title{
Type II endometrial cancers: original research on a series
}

\author{
B. L. Nayak ${ }^{1}$, Sujata Misra ${ }^{2 *}$, Suryakant Jaysingh ${ }^{2}$, S. K. Giri ${ }^{1}$
}

${ }^{1}$ Department of Obstetrics and Gynecology, AHRRC, Cuttack, Odisha, India
${ }^{2}$ Department of Obstetrics and Gynecology, SCB, Cuttack, Odisha, India

Received: 15 May 2017

Accepted: 19 May 2017

*Correspondence:

Dr. Sujata Misra,

E-mail: drsujatamisra@gmail.com

Copyright: (c) the author(s), publisher and licensee Medip Academy. This is an open-access article distributed under the terms of the Creative Commons Attribution Non-Commercial License, which permits unrestricted non-commercial use, distribution, and reproduction in any medium, provided the original work is properly cited.

\section{ABSTRACT}

Background: Endometrial carcinoma, which ranks $3^{\text {rd }}$ in India amongst the gynecological malignancies, is of two histological types: I and II. These differ in molecular as well as in clinical and histopathological profiles. Type II is estrogen independent, nonendometrioid, with higher grade histologies, more aggressive and carries an adverse prognosis.

Methods: Endometrial carcinomas diagnosed from endometrial biopsies and hysterectomy specimens in the Dept of Gynaec-oncology, AHRCC, Cuttack from November 2009 to January 2015 were included in the study. All specimens were fixed in $10 \%$ neutral buffered formalin and paraffin embedded for histological examination with hematoxylin and eosin staining. The clinicopathological analysis of the cases of EC was done with an emphasis on morphology.

Results: Of a total of 150 cases of EC reported, 20 cases were classified as type II EC (13.33\%) as per histology. The age of the patients ranged from 36 to 73 years, with mean age is 61 years. In 11 cases (55\%), the myometrial invasion was more than half. the histological type was a clear cell adenocarcinoma in $50 \%$ of the cases. All were treated with hysterectomy and chemotherapy.

Conclusions: Of the type II EC, serous carcinoma is the most common type. Clinical presentation and prognosis differs in comparison to type I EC, thus the recognition of this type of EC is pivotal.

Keywords: Clear cell adenocarcinoma, Estrogen independent, Gynecological malignancies, Type II endometrial cancer

\section{INTRODUCTION}

Endometrial carcinoma, the $3^{\text {rd }}$ commonest gynecological malignancy in india, is usually of two distinct histological groups - type I and type II. ${ }^{1,2}$

These differ in clinical and histopathological profiles. Type II is nonestrogen dependent, nonendometrioid, with a poor prognosis. 3,4

They ususlly present at an advanced age and contribute to about $10 \%$ of the cases of endometrial carcinoma, but the recurrence rate is almost $50 \% .^{5}$

\section{METHODS}

The patients enrolled in this were those patients who attended the Gynaecological oncology OPD of Acharya Harihar regional cancer centre from NOV 2009 to JAN 2015. Endometrial carcinoma was diagnosed from endometrial biopsies and hysterectomy specimens. All specimens were fixed in $10 \%$ neutral buffered formalin and paraffin embedded for histological examination with hematoxylin and eosin staining.

The clinicopathological analysis of the cases of EC was done with emphasis on morphology and the results were analysed. 


\section{RESULTS}

During the study period, a total of 150 cases of EC were reported. Out of these, 20 cases were classified as type II EC $(13.33 \%)$ as per histology. The age of the patients ranged from 36 to 73 years, with mean age being 61 years.

The clinical presentation was- postmenopausal bleeding in $80 \%$ of the cases, menorrhagia in $5 \%$ and metrorrhagia in $5 \%$, abdominal mass in $5 \%$. All of them underwent surgery. CSS was done for 14 cases $(70 \%)$, TAH+BSO for $3(15 \%)$ cases out of which 2 presented with distance metastasis.

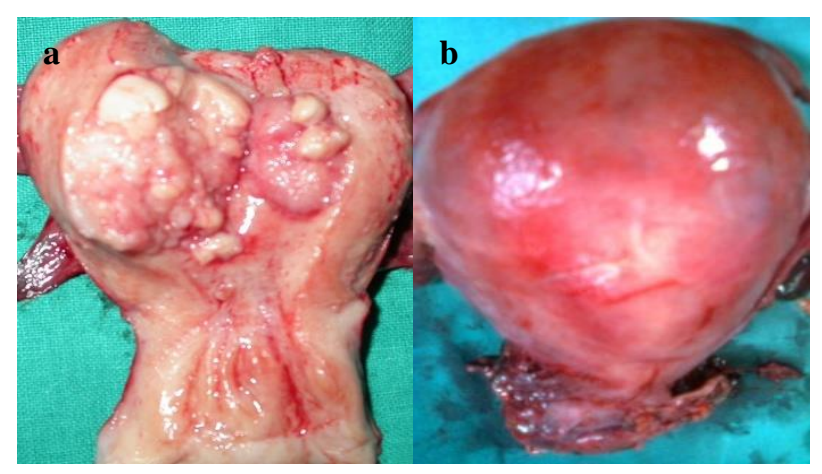

Figure 1: Gross appearance of the specimen and Cavity filled with polypoid growth on cut section.

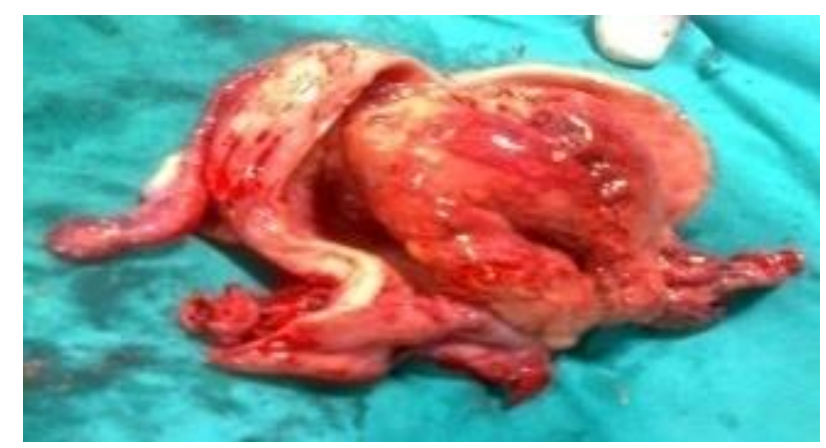

Figure 2: Polypoidal growth at fundus on cut section of the specimen.

Modified radical hysterectomy was done for $3(15 \%)$ cases and they were followed by chemotherapy 6 cases (30\%)/radiotherapy 3 cases $(15 \%)$. Nodal status showed that $15 \%$ had pelvic lymph node +ve, $20 \%$ had paraaortic lymph node +ve and $10 \%$ cases had distance metastasis. While $70 \%$ of the cases were followed up for one year, $10 \%$ of the cases were followed up to one year $20 \%$ cases were lost to follow up. There was a $10 \%$ recurrence of disease treated by brachytherapy.

\section{Gross}

The type II EC frequently appeared bulky on a background of an atrophic endometrium, with tumor filling almost the entire cavity (Figure $1 \mathrm{a}$ and $\mathrm{b}$ ).
Myometrial invasion was more than half for 11 cases (55\%) less than $50 \%$ in 6 cases $(30 \%)$ (Figure 2). There was distance metastasis in 2 cases $(10 \%)$ and no myoinvasion in 1 case $(5 \%)$. Hisopathological study showed that $50 \%$ of the cases were clear cell adenocarcinoma, 355 were UPSC and $15 \%$ of the cases were adenocarcinoma.

\section{DISCUSSION}

Type II endometrial carcinomas are not related to estrogen and are the nonendometrioid types. They usually arise in the setting of endometrial atrophy, and usually occur in women a decade later than type I carcinoma. Serouc carcinoma is the most common type II endometrial carcinoma and these have higher case-fatality rate than their more common endometrioid counterparts. ${ }^{6}$

The prognosis is largely influenced by the patient's age at the time of diagnosis. ${ }^{7}$ Generally, premenopausal endometrial carcinoma is associated with a 5-year survival approaching $100 \% .^{8}$

In our series, the mean age was 61 years, and the histomorphological features were of high grade (poorly differentiated). Out of the 150 cases of EC reported during the study period, 7 were serous carcinoma and 10 were clear cell carcinoma and 3 were adenosquamous. This showed that clear cell carcinomas were the most common type of type II ECs. Uterine bleeding in the postmenopausal woman was the major presenting feature.

Myoinvasion, described by the presence of irregular, jagged contours of the neoplastic glands, single tumor cells or clusters in the myometrium, desmoplastic stroma and haphazard distribution of neoplastic glands in myometrium is an important histological finding. ${ }^{9}$ Once myoinvasion is established, the depth of invasion is measured using the deepest undulation of endomyometrial junction.

Patients with more than $50 \%$ myometrial thickness invasion are at increased risk for extrauterine metastases, including pelvic and para-aortic lymph node metastases. These patients often require pelvic and para-aortic lymphadenectomy, as well as postoperative adjunctive therapy. ${ }^{10}$

In present findings, seven of the cases $(55 \%)$ had more than half of myometrial thickness invasion. Two of the cases had distant metastases to the liver. Postoperative chemotherapy was given additionally to the cases with distant metastases. Our case series shows that the incidence of type II EC is less than that of type I.

Among the type II EC, serous carcinomas are higher in number. The aggressiveness and the poorer survival rates of type II EC makes the diagnosis of this type very crucial for the histopathologist and the clinician. 
Table 1: Staging (FIGO 2009, surgico-pathological).

\begin{tabular}{|c|c|c|c|c|c|c|}
\hline Age & $\begin{array}{l}\text { Nature of } \\
\text { specimen }\end{array}$ & Diagnosis & $\begin{array}{l}\text { Stage / } \\
\text { Grade }\end{array}$ & Gross features & $\begin{array}{l}\text { Myometrial } \\
\text { invasion }\end{array}$ & Follow up \\
\hline 65 & $\begin{array}{l}\text { Modified radical } \\
\text { hysterectomy } \\
+\mathrm{BSO}\end{array}$ & UPSC & $\begin{array}{l}\text { IIIC2, } \\
\text { N1MO }\end{array}$ & $\begin{array}{l}\text { Necrotic growth. } \\
\text { extension to cervix }\end{array}$ & $>50 \%$ & $\begin{array}{l}\text { CT, } 1 \mathrm{yr} \\
\text { NED }\end{array}$ \\
\hline 50 & CSS & Clear cell & IB,G 3 & $\begin{array}{l}\text { Cavity filled with } \\
\text { polypoid growth. }\end{array}$ & $>50 \%$ & 2yr, NED \\
\hline 54 & CSS & UPSC & IB,G1 & Thickened endomerium & $>50 \%$ & 1yr, NED \\
\hline 60 & CSS & Clear cell & $\begin{array}{l}\text { IIIC1, } \\
\text { N1MO }\end{array}$ & $\begin{array}{l}\text { Polypoidal growth at } \\
\text { fundus }\end{array}$ & $<50 \%$ & RT,1yr NED \\
\hline 67 & CSS & Clear cell & $\begin{array}{l}\text { IIIC2, } \\
\text { N1M0 }\end{array}$ & $\begin{array}{l}\text { Cavity filled with } \\
\text { growth }\end{array}$ & $>50 \%$ & CT,1yr NED \\
\hline 68 & CSS & Clear cell & I A,G3 & $\begin{array}{l}\text { Growth filling the entire } \\
\text { cavity }\end{array}$ & $<50 \%$ & $\begin{array}{l}\text { 2yr, NED, } \\
\text { Recur (Rx } \\
\text { brachy) THN } \\
\text { 1yr NED }\end{array}$ \\
\hline 51 & CSS & Clear cell & IA,G3 & $\begin{array}{l}\text { UT size } 10 \mathrm{WK}, 3 \text { luminal } \\
\text { growth }\end{array}$ & No invasion & \\
\hline 64 & CSS & Clear cell & $\begin{array}{l}\text { IIIC1 } \\
\text { N1M0 }\end{array}$ & $\begin{array}{l}\text { Growth filling endo } \\
\text { cavity }\end{array}$ & $>50 \%$ & RT,1yr NED \\
\hline 46 & CSS & UPSC & $\mathrm{IA}, \mathrm{G} 3$ & $\begin{array}{l}\text { Soft friable growth in } \\
\text { cavity }\end{array}$ & $<50 \%$ & \\
\hline 70 & $\begin{array}{l}\text { TAH+BSO, } \\
\text { Omentectomy }\end{array}$ & Clear cell & $\begin{array}{l}\text { IVB, } \\
\text { N1M1 }\end{array}$ & $5 * 4 \mathrm{CM}$ mass in cavity & $>50 \%$ & CT \\
\hline 65 & $\mathrm{TAH}+\mathrm{BSO}$ & UPSC & $\begin{array}{l}\text { IVB, } \\
\text { N1M1 }\end{array}$ & Growth filling cavity & $>50 \%$ & CT \\
\hline 61 & $\begin{array}{l}\text { Modified radical } \\
\text { hysterectomy }\end{array}$ & UPSC & II,G2 & Growth invades CX & $<50 \%$ & 1yr, NED \\
\hline 50 & $\mathrm{TAH}+\mathrm{BSO}$ & Clear cell & IIG3 & Growth filling cavity & $>50 \%$ & 1yr, NED \\
\hline 53 & CSS & Adenosquamous & $\mathrm{IB}, \mathrm{G} 3$ & Growth filling cavity & $>50 \%$ & $\begin{array}{l}\text { 2yr, THN } \\
\text { REC-RT }\end{array}$ \\
\hline 40 & CSS & Adenosquamous & IA, G2 & Growth filling cavity & $<50 \%$ & 1yr, NED \\
\hline 58 & CSS & Clear cell & $\begin{array}{l}\text { IIIC2, } \\
\text { N1M0 }\end{array}$ & Growth filling cavity & $>50 \%$ & RT,1yr, NED \\
\hline 73 & CSS & UPSC & $\mathrm{IB}, \mathrm{G} 3$ & Growth filling cavity & $>50 \%$ & 1yr NED \\
\hline 52 & CSS & adenosquamous & $\begin{array}{l}\text { IIIC1 } \\
\text { N1M0 }\end{array}$ & $\begin{array}{l}2 \text { polypoidal growth in } \\
\text { cavity }\end{array}$ & $<50 \%$ & $\begin{array}{l}\text { RT, } 2 y r, \\
\text { NED }\end{array}$ \\
\hline 65 & $\begin{array}{l}\text { Modified radical } \\
\text { hysterctomy }\end{array}$ & Clear cell & $\begin{array}{l}\text { II, } \\
\text { NOM0 }\end{array}$ & $\begin{array}{l}\text { Fluid in cavity, growth } \\
\text { towards CX }\end{array}$ & $>50 \%$ & 1yr, NED \\
\hline 36 & CSS & UPSC & $\begin{array}{l}\text { IIIC2, } \\
\text { N1M0 }\end{array}$ & $\begin{array}{l}\text { Extensive growth in } \\
\text { cavity involving vagina }\end{array}$ & $>50 \%$ & CT, 2yr NED \\
\hline
\end{tabular}

\section{CONCLUSION}

This study series shows that the incidence of type II EC is less than that of type I. Among the type II Endometrial cancers, the histological type was mainly clear cell carcinomas. The diagnosis of this entity is important due to the aggressiveness and the poorer survival rates of type II EC. Early and accurate diagnosis and proper postsurgical evaluation and treatment is mandatory.

Funding: No funding sources Conflict of interest: None declared
Ethical approval: The study was approved by the Institutional Ethics Committee

\section{REFERENCES}

1. Bokhman JV. Two pathogenetic types of endometrial carcinoma. Gynecol Oncol. 1983;15:10-7.

2. Devi K. Current status of gynecological cancer care in India. J Gynecol Oncol. 2009;20:77-80.

3. Mendivil A, Schuler KM, Gehrig PA. Nonendometrioid adenocarcinoma of the uterine corpus: A review of selected histological subtypes. Cancer Control. 2009;16:46-52. 
4. Bansal N, Yendluri V, Wenham RM. The molecular biology of endometrial cancers and the implications for pathogenesis, classification, and targeted therapies. Cancer Control. 2009;16:8-13.

5. Singh P, Smith CL, Cheetham G, Dodd TJ, Davy ML. Serous carcinoma of the uterus-determination of HER-2/neu status using immunohistochemistry, chromogenic in situ hybridization, and quantitative polymerase chain reaction techniques: Its significance and clinical correlation. Int J Gynecol Cancer. 2008; 18:1344-51.

6. Fadare O, Zheng W. Insights into endometrial serous carcinogenesis and progression. Int $\mathrm{J}$ Clin Exp Pathol. 2009;2:411-32.

7. Abeler VM, Kjørstad KE. Endometrial adenocarcinoma in Norway. A study of a total population. Cancer. 1991;67:3093-103.
8. Connelly PJ, Alberhasky RC, Christopherson WM. Carcinoma of the endometrium. III. Analysis of 865 cases of adenocarcinoma and adenoacanthoma. Obstet Gynecol. 1982;59:569-75.

9. Ali A, Black D, Soslow RA. Difficulties in assessing the depth of myometrial invasion in endometrial carcinoma. Int J Gynecol Pathol. 2007;26:115-23.

10. Larson DM, Connor GP, Broste SK, Krawisz BR, Johnson KK. Prognostic significance of gross myometrial invasion with endometrial cancer. Obstet Gynecol. 1996;88:394-8.

Cite this article as: Nayak BL, Misra S, Jaysingh S, Giri SK. Type II endometrial cancers: original research on a series. Int J Reprod Contracept Obstet Gynecol 2017;6:2306-9. 